\title{
An Empirical Analysis of the Effect of Total Factor Productivity on Manufacturing Performance
}

\author{
Hongbo Zhang, Jianyuan $\mathrm{Wu}^{*}$ and Nian Zhong \\ Business School, Nanjing University of Information Science \& Technology, Ningliu Road 219\# Nanjing City Jiangsu Province \\ China \\ ${ }^{*}$ Corresponding author
}

\begin{abstract}
As the basic industry of national economy, manufacturing industry plays an important role in promoting China's economic development. In this paper, the total factor productivity of the manufacturing sector is calculated based on the statistics of 16 industrial sectors from 2002 to 2015. It is found that the manufacturing efficiency of our country decreased in 2002-2015. Among them, petroleum processing, coking and nuclear fuel industry fluctuate the most. From 2002 to 2015, the total factor productivity of every industry in the manufacturing industry experienced the trend of declining and then recovering, and the overall trend was declining. As for arts and crafts and other manufacturing industries, the total factor productivity of each year has experienced a trend of rising and then falling slightly, and the overall trend is on the rise. Overall, total factor productivity in all sectors of the manufacturing sector has declined. Therefore, it is necessary to improve the efficiency of resource utilization, improve inter-industry resource allocation and improve total factor productivity, so as to maintain a strong competitive advantage.
\end{abstract}

Keywords-manufacturing industry; performance; C-D function

\section{INTRODUCTION}

After the reform and opening up, China has been actively involved in the development of the world economy. China's manufacturing sector now generates a third of GDP, contributing $90 \%$ of its exports. From 1978-1998, our country scale manufacturing output, the calculated at comparable caliber, the average annual growth of about $15 \%$, higher than the entire industry with an average annual GDP growth, since then, the processing trade in both as a share of GDP growth, or pull on economic growth are highlighted the importance of it. In particular, from 1998 to 2008, the contribution of processing trade to economic growth reached an average of $58.6 \%$ per year, and the pull of economic growth was 4.8 percentage points (8\% GDP growth rate). Every 10 per cent growth in China's manufacturing sector boosts global growth by 1 percentage point. China plays a unique role in the global manufacturing system. It is not only the partner of other countries and regional industries, but also an important part of the vertical division of labor -- the world manufacturing center.

Science and technology is the primary productive force, the competition of modern enterprises has become increasingly dependent on science and technology, and the strengthening of technological innovation has become a new trend in the development of modern enterprises. Enterprise technology innovation is divided into original innovation mode, catch up with the innovation mode, local standard leading innovation, market innovation, innovation mode, etc., no matter which kind of innovation mode in the final analysis requires the appropriate cooperation innovation, introduction of some key technology, the ultimate goal is to improve the independent innovation ability of the enterprise. From the point of long-term development, enterprises should put the independent research and the development of independent innovation as the main strategy, efforts to improve the level of enterprise technology innovation, to ensure that enterprises in the fierce market competition to improve the core competitiveness. The input of material capital provides the foundation for technological innovation, and the investment of enterprise material capital can improve the technology of enterprises and help enterprises to establish competitive advantages.

The impact of labor input on performance is also crucial. From the perspective of human capital, the training of employees can not only improve the productivity of employees, but also promote the improvement of other production efficiency. The development of modern economy shows that the contribution of human capital development and accumulation to economic growth exceeds the growth efficiency brought by the increase of material capital.

\section{THEORETICAL BASIS AND IMPORTANT CONCEPT DEFINITION}

\section{A. Introduction of Production Functions}

The measurement method of scientific and technological progress has a lot of, at present more popular is the production function (C - D production function for short) based on variant and Solow residual method, get through the remainder term indicates the degree of technological progress.

The c-d production function was originally created by American economists p. h. Douglas and c. w. Cobb to explore the relationship between output and input, and in 1942, Dingbogen made significant improvements. $50 \mathrm{~s}$, the famous American economist Solow growth rate equation model is established, accordingly to the residual method calculating the extent of the progress of science and technology, this method also gives the production function.

Economic growth is the result of multiple factors. Labor, science and technology, capital, policies, resources, industrial structure and so on will have an impact on the economic operation. But in the real world, apart from labor and capital, these two factors are measurable, and other factors are difficult 
to measure. So, in the use of C - D function to measure science and technology progress, the usual method is to eliminate the secondary factors, key seize the labor, capital and technology progress of the three elements, and economically to make economic assumptions as follows:

(1) in the case of only capital and labor force, these two factors can be substituted for each other and can be coordinated with a variable ratio;

(2) under any circumstances, capital and Labour can be fully utilized;

(3) in the case of perfect competition, capital and labor are paid as marginal products;

(4) technological progress refers to hicks' neutral technological progress. When the ratio of capital to labor is constant, the marginal product of the technological progress remains unchanged, i.e., the marginal replacement rate remains unchanged.

\section{B. Total Factor Productivity}

Total factor productivity (TFP) total factor productivity generally means the efficiency of exploitation and utilization of resources (including manpower, material resources and financial resources). The elements of this article refers to the total factor productivity (such as capital and labor) into the cause of technology progress and ability to achieve rather than output increase, the contribution is to eliminate inputs of residual after, first put forward by Thoreau (Solow, 1957), also known as the Solow residual.

\section{MEASUREMENT OF TOTAL FACTOR PRODUCTIVITY}

\section{A. Measurement Method of Total Factor Productivity}

The estimation method of total factor productivity can be summed up in two categories: one is the growth accounting method and the other is the economic measurement method. The growth accounting method is based on the theory of neoclassical growth, the estimation process is relatively simple and the factors are less, but the main disadvantage is that the constraint is strong and rough. The economic measurement method USES various econometric models to estimate the total factor productivity, and considers the influence of various factors in a more comprehensive way, but the estimation process is more complicated.

\section{B. Calculation of Total Factor Productivity}

In this paper, the influence of total factor productivity changes of 16 industrial sectors in China's industrial manufacturing sector was analyzed, and DEA-Malmquist data processing method was used to measure the total factor productivity changes of each manufacturing industry.

The basic assumption of the data envelopment analysis (DEA) model is that economies face the same technological frontier. This model through the calculation of productivity levels of economies (described by the input and output) to the relative change of the distance between the technological frontier to measure economy to enhance the Efficiency of production, and further to the improvement of production Efficiency is decomposed into Technical Efficiency, Technical
Efficiency) and technological Progress, Technical Progress). The core of DEA model is to define distance function to measure the gap between economy and technology frontier. On the basis of distance function, using linear optimization algorithm, through the observation of sample points inputoutput statistics (economy) to build the technological frontier and calculating the distance of the economies from the technological frontier.

The corresponding DEA-Malmquist model is established according to the research problem. In the period of $t$ to $t+1$, total factor productivity growth can be measured by the following Malmquist index:

$\mathrm{M}_{0}=\left(\mathrm{x}_{\mathrm{t}+1}, \mathrm{y}_{\mathrm{t}+1}, \quad \mathrm{x}_{\mathrm{t}}, \mathrm{y}_{\mathrm{t}}\right)=\left[\frac{D_{0}^{\mathrm{t}}\left(\mathrm{x}_{\mathrm{t}+1}, \mathrm{y}_{\mathrm{t}+1}\right)}{D_{0}^{\mathrm{t}}\left(x_{t}, y_{t}\right)} \times \frac{D_{0}^{\mathrm{t}+1}\left(\mathrm{x}_{\mathrm{t}+1}, \mathrm{y}_{\mathrm{t}}\right)}{D_{0}^{\mathrm{t}+1}\left(\mathrm{x}_{\mathrm{t}}, \mathrm{y}_{\mathrm{t}}\right)}\right]^{1 / 2}$

Among them, the input and output of $t+1$ and $t$ period are $\left(\mathrm{x}_{\mathrm{t}+1}, \mathrm{y}_{\mathrm{t}+1}\right)$ and $\left(\mathrm{x}_{\mathrm{t}}, \mathrm{y}_{\mathrm{t}}\right) ; D_{0}^{\mathrm{t}}$ and $D_{0}^{\mathrm{t}+1}$ respectively denote the distance function of period $t$ and period $t+1$ referring to t period technique $\mathrm{T}$, respectively.

\section{Calculation Process}

1) Data sources: This paper mainly selects the relevant data of China's manufacturing industry from 2002 to 2015 from the statistical yearbook of China. According to DEA model, the selected variables should not only reflect the influence of input change on output, but also accurately reflect the evaluation. Therefore, for the input indicators, this paper selects the labor force (i.e. the average number of all employees in the manufacturing industry) and the capital stock, and the output index is the total profit of each manufacturing industry at the end of the year. The selection of the number of labor employment are industrial enterprises above designated size, capital stock data from 2001 to 2014 mainly comes from the industrial economic review 2017, 6, 2015 data due to the lack of original data to calculate, using grey prediction software GM1.1 model to forecast selection and merger of industry.

2) Selection and merger of industry: This article selects the manufacturing industry in our country as the research object, according to China's energy statistics yearbook 2002-2015, the energy consumption of manufacturing division of department of statistics, and considering the subtle changes in 2005 to 2015, after merger, will be from 2002 to 2015, China's manufacturing industry into 16 industrial sectors (such as agricultural food processing, food manufacturing, wine, beverage and refined tea manufacturing and tobacco products for food production and tobacco processing industry; Textile industry and textile and apparel industry are merged into textile industry, as shown in table 1. 
TABLE I. MANUFACTURING SECTOR.

\begin{tabular}{|c|c|c|c|}
\hline 1 & $\begin{array}{c}\text { Food manufacturing and } \\
\text { tobacco processing industry }\end{array}$ & 9 & $\begin{array}{c}\text { Metal smelting and } \\
\text { Calendering Industry }\end{array}$ \\
\hline 2 & Cottonocracy & 10 & Metal products industry \\
\hline 3 & $\begin{array}{c}\text { Leather, fur, feather (velvet) } \\
\text { and its products }\end{array}$ & 11 & $\begin{array}{c}\text { General purpose equipment } \\
\text { manufacturing industry }\end{array}$ \\
\hline 4 & $\begin{array}{c}\text { Wood processing and } \\
\text { furniture manufacturing }\end{array}$ & 12 & $\begin{array}{c}\text { Transportation equipment } \\
\text { manufacturing industry }\end{array}$ \\
\hline 5 & $\begin{array}{c}\text { Papermaking and stationery } \\
\text { manufacturing industry }\end{array}$ & 13 & $\begin{array}{c}\text { Electrical machinery and } \\
\text { equipment manufacturing } \\
\text { industry }\end{array}$ \\
\hline 6 & $\begin{array}{c}\text { Electrical machinery and } \\
\text { equipment manufacturing } \\
\text { industry }\end{array}$ & 14 & $\begin{array}{c}\text { Communications } \\
\text { equipment, computers and } \\
\text { other electronic equipment }\end{array}$ \\
\hline 7 & Chemical industry & 15 & $\begin{array}{c}\text { Instrument manufacturing } \\
\text { industry }\end{array}$ \\
\hline 8 & $\begin{array}{c}\text { Nonmetallic mineral } \\
\text { products industry }\end{array}$ & 16 & $\begin{array}{c}\text { Handicrafts and other } \\
\text { manufacturing industries } \\
\text { (including scrap) }\end{array}$ \\
\hline
\end{tabular}

3) Malmquist productivity index measurement: This paper USES the existing DEA model to measure the total factor productivity changes of China's manufacturing industry from 2001 to 2015.

Because there is a negative value in the total profit data, it is necessary to standardize the data. The standardized formula used is:

$$
\mathrm{X}^{\prime}=0.1+0.9 *(\mathrm{x}-\mathrm{min}) /(\max -\mathrm{min}) \text {. }
$$

$\mathrm{X}$ is the original data, $\mathrm{X}$ 'is the data after standardized processing, MAX and MIN are the maximum and minimum values respectively, and the interval range of $X^{\prime}$ is $[0.1,1]$. The annual data are then processed according to the standardized formula.

\section{CALCUlation Results AND ANALysis of TOTAL FACTOR PRODUCTIVITY}

\section{A. Calculation Results of Total Factor Productivity}

Through the operation, we can see the total factor productivity calculation results of 16 industries from 2002 to 2015. The corresponding Numbers of each industry are shown in table 1 , and the results are shown in table 2 below.
TABLE II. CALCULATION RESULTS OF TOTAL FACTOR PRODUCTIVITY IN EACH CALENDAR YEAR

\begin{tabular}{|c|c|c|c|c|c|c|c|}
\hline Industry & $2001-$ & $2002-$ & $2003-$ & $2004-$ & $2005-$ & $2006-$ & $2007-$ \\
& 2002 & 2003 & 2004 & 2005 & 2006 & 2007 & 2008 \\
\hline 1 & 1.276 & 1.077 & 0.948 & 0.901 & 1.149 & 1.322 & 1.038 \\
\hline 2 & 1.291 & 1.019 & 0.881 & 1.051 & 1.197 & 1.107 & 1.302 \\
\hline 3 & 1.062 & 1.021 & 0.894 & 1.147 & 1.236 & 0.743 & 2.013 \\
\hline 4 & 0.994 & 1.033 & 0.946 & 1.192 & 1.238 & 0.769 & 1.922 \\
\hline 5 & 1.241 & 0.966 & 0.855 & 0.981 & 1.224 & 0.953 & 1.516 \\
\hline 6 & 1.612 & 1.380 & 1.243 & 0.413 & 1.029 & 1.552 & 0.693 \\
\hline 7 & 1.464 & 1.162 & 1.031 & 0.765 & 1.010 & 1.525 & 0.906 \\
\hline 8 & 1.181 & 1.307 & 0.954 & 0.882 & 1.281 & 1.191 & 1.342 \\
\hline 9 & 1.423 & 1.467 & 1.170 & 0.720 & 1.198 & 1.369 & 0.679 \\
\hline 10 & 1.124 & 1.059 & 0.922 & 0.988 & 1.148 & 0.851 & 1.562 \\
\hline 11 & 1.491 & 1.122 & 0.983 & 0.991 & 1.191 & 1.272 & 1.051 \\
\hline 12 & 1.583 & 1.200 & 0.739 & 0.643 & 1.254 & 1.298 & 1.093 \\
\hline 13 & 1.223 & 1.026 & 0.909 & 0.919 & 1.166 & 1.131 & 1.271 \\
\hline 14 & 1.040 & 0.982 & 0.848 & 0.740 & 1.120 & 1.058 & 1.092 \\
\hline 15 & 0.984 & 1.077 & 0.868 & 1.180 & 1.225 & 0.752 & 1.929 \\
\hline 16 & 0.911 & 1.314 & 0.868 & 1.282 & 1.260 & 0.701 & 2.139 \\
\hline Industry & $2008-$ & $2009-$ & $2010-$ & $2011-$ & $2012-$ & $2013-$ & $2014-$ \\
\hline 1 & 2009 & 2010 & 2011 & 2012 & 2013 & 2014 & 2015 \\
\hline 2 & 1.114 & 0.889 & 0.991 & 1.118 & 0.945 & 0.940 & 0.939 \\
\hline 3 & 0.972 & 0.973 & 0.993 & 1.023 & 1.004 & 1.019 & 0.945 \\
\hline 4 & 0.578 & 0.965 & 0.994 & 1.065 & 0.958 & 1.051 & 0.923 \\
\hline 5 & 0.629 & 0.948 & 1.026 & 1.062 & 0.987 & 1.005 & 0.917 \\
\hline 6 & 0.744 & 0.923 & 0.953 & 1.191 & 0.919 & 1.069 & 0.948 \\
\hline 7 & 1.186 & 0.857 & 0.539 & 0.911 & 1.126 & 0.710 & 1.542 \\
\hline 8 & 0.948 & 0.947 & 1.021 & 0.935 & 1.025 & 0.990 & 0.870 \\
\hline 9 & 0.873 & 0.998 & 0.958 & 0.831 & 0.843 & 1.034 & 0.647 \\
\hline 10 & 0.712 & 0.977 & 0.963 & 1.041 & 0.936 & 0.969 & 0.904 \\
\hline 11 & 1.061 & 0.920 & 0.979 & 0.959 & 0.957 & 0.969 & 0.912 \\
\hline 12 & 1.194 & 0.951 & 0.922 & 0.975 & 1.062 & 1.035 & 0.944 \\
\hline 13 & 0.975 & 0.881 & 0.863 & 1.000 & 0.957 & 1.093 & 0.980 \\
\hline 14 & 0.938 & 0.922 & 0.943 & 1.052 & 0.972 & 1.165 & 0.956 \\
\hline 15 & 0.556 & 0.921 & 0.980 & 0.980 & 1.052 & 1.055 & 0.935 \\
\hline 16 & 0.532 & 0.983 & 1.023 & 0.811 & 1.170 & 1.075 & 0.924 \\
\hline
\end{tabular}

\section{B. Analysis of the Results of Total Factor Productivity}

By measuring results can be seen that, from 2002 to 2002, manufacturing industries from food production and tobacco processing industry to instrument manufacturing industry, the industry $1-15$, the total factor productivity of calendar year have undergone a fall first, then the trend of recovery, the last is a downward trend in general; And handicraft and other manufacturing industry, namely the industry 16, the total factor productivity of the calendar year experienced the trend that rises first and then drops slightly, overall shows an upward trend. Overall, total factor productivity in all sectors of the manufacturing sector has declined.

The main reason for the decline in the total factor productivity of the manufacturing industry is the premature entry into the process of capital deepening, the creation of fewer and fewer jobs, the emergence of layoffs and the peak of unemployment; Second, more and more unequal income distribution, all kinds of rent-seeking activities are very active, all kinds of social cost has increased dramatically, not only directly affect the economic growth, but also directly or indirectly affect the welfare of the masses of the people. It can be concluded that the low quality of economic growth, which relies heavily on capital input, massive consumption of resources and a large amount of emission pollution, is 
unsustainable. Therefore, it is very important to abandon the traditional pursuit of high growth and investment-driven growth rate strategy, and turn to the new strategy of pursuing economic growth quality and efficiency and productivitydriven growth. At the same time, the overall manufacturing sector needs to shift from low employment growth to high employment growth. Never fair growth to equitable growth; Shifting from sustainable growth to sustainable growth; To further improve the quality of policies and the quality of government management.

\section{Policy Suggestions}

For total factor productivity, its main sources include technological progress and institutional reform. Manufacturing industry in our country internal gap between the production efficiency is very obvious, this requires breaking elements such as capital and labor departments in various fields between the flow of disorder, make resources can get better allocation efficiency, further improve the total factor productivity.

First, we should improve the system and mechanism of market allocation resources and create a competitive environment for equal access and exit. There is also an important area for improving total factor productivity, which is that there are huge productivity differences within the industry, which can also increase productivity if the barriers to entry and exit are reduced.

Secondly, through the reform of financial system, the efficiency of factor allocation is improved. The reform of financial system should focus on the promotion of interest rate liberalization. Only market-oriented interest rate can realize the effective allocation of capital. Under the non-marketable interest rate, the interest rate cannot fluctuate with the return on capital; the production efficiency and the allocation efficiency are all below the optimal level, which leads to the decline of total factor productivity.

Finally, through the reform of the household registration system to promote the citizenization of migrant workers, we will continue to create resources to re-allocate efficiency. Through public policy reform, and promote rural surplus labor transfer and urbanization of rural migrant workers, further can improve potential growth by increasing the labor supply, can also by eliminating the institutional barriers to labor migration channels, by continuing to create resource reconfiguration efficiency, make the total factor productivity improved. Furthermore, because of the labor force to profitability was positively to the influence of the assets, increase labor force can not only make the total factor productivity was improved, but also can promote the development of assets profit margins are.

\section{ACKNOWLEDGEMENT}

This paper is the research result of the 2011 graduate innovation project 070621 in Jiangsu province, China.

\section{REFERENCES}

[1] Y. Yorozu, M. Hirano, K. Oka, and Y. Tagawa, "Electron spectroscopy studies on magneto-optical media and plastic substrate interface,” IEEE Transl. J. Magn. Japan, vol. 2, pp. 740-741, August 1987 [Digests 9th Annual Conf. Magnetics Japan, p. 301, 1982].
[2] Banerjee, Abhijit, and Esther Duflo, 2005, "Growth Theory through the Lens of Development Economics”, in Handbook of Economic Growth, Vol. 1A, P. Aghion and S. Durlauf, eds. (Amsterdam: Elsevier, Chap. 7) .

[3] Bosworth, Barry, and Susan M. Collins, 2007, “Accounting for Growth: Comparing China and India”, NBER Working Paper No. w12943.

[4] Bloom, N., and J. V. Reenen, 2007, "Measuring and Explaining Management Practices across Firms and Countries”, Quarterly Journal of Economics, 24, 203-224.

[5] Brandt, Loren, Johannes Van Biesebroeck, and Yifan Zhang, 2011, "Creative Accounting or Creative Destruction? Firm-Level Productivity Growth in Chinese Manufacturing”, Journal of Development Economics, 97, 339-351.

[6] Broda, Christian, and David E. Weinstein, 2006, "Globalization and the Gains from Variety”, Quarterly Journal of Economics, 121, 541-585.

[7] Foster, Lucia, John Haltiwanger, and Chad Syverson, 2008, "Reallocation, Firm Turnover, and Efficiency: Selection on Productivity or Profitability?”, American Economic Review, 98, 394-425.

[8] Hendel, Igal, and Aviv Nevo, 2006, "Measuring the Implications of Consumer Inventory Behavior”, Econometrica, 74 , 1637-1673.

[9] Hsieh, Chang-Tai, and Peter J. Klenow, 2009, "Misallocation and Manufacturing TFP in China and India”, Quarterly Journal of Economics, $124,1403-1448$.

[10] Levinsohn, J. , and A. Petrin, 2003, "Estimating Production Functions Using Inputs to Control for Unobservables”, Review of Economic Studies, 70, 317-42.

[11] Melitz, Marc J. , 2003, “The Impact of Trade on Intra-Industry Reallocations and Aggregate Industry Productivity”, Econometrica, 71, 1695-1725.

[12] Olley, G. Steven, and Ariel Pakes, 1996, "The Dynamics of Productivity in the Telecommunications Equipment Industry”, Econometrica, 64, 1263-1297.

[13] Petrin, A. , B. Poi, and J. Levinsohn, 2004, "Production Function Estimation in Stata Using Inputs to Control for Observables", Stata Journal, 4, 113-123.

[14] Restuccia, Diego, and Richard Rogerson, 2008, "Policy Distortions and Aggregate Productivity with Heterogeneous Plants”, Review of

$$
\text { Economic Dynamics, 11, 707-720. }
$$

[15] Banker R. D, A Charnes, W. W. Cooper, Some models for estimating technical and scale ine fficiencies in data envelopment analysis[J], Management Science, 1984, 30: 1078 1092.

[16] Farrell M. J, The measurement of productive e fficiency[J], Journal of the Royal Statistical Society, Series A., 1957, 120: 253 281.

[17] Caves D. W, L. R. Christensen, W. E. Diewert, The economic theory of index numbers and the measurement of input, output, and productivity[J], Econometrica, 1982, 50: 1393 1414.

[18] Charnes A. Cooper W. W., Rhodes E, Measuring the efficiency of decision making units[J],European Journal of Operational Research, 1978, 2: 429 444 